Hydrol. Earth Syst. Sci. Discuss., doi:10.5194/hess-2017-100, 2017

Manuscript under review for journal Hydrol. Earth Syst. Sci.

Discussion started: 28 March 2017

\title{
Hydrologic modeling of a Himalayan mountain basin by using the SWAT model
}

\author{
Sharad K. Jain ${ }^{*}$, Sanjay K. Jain ${ }^{1}$, Neha Jain ${ }^{1}$ and Chong-Yu Xu ${ }^{2}$ \\ ${ }^{1}$ National Institute of Hydrology, Roorkee 247667, India \\ ${ }^{2}$ University of Oslo, Oslo, Norway \\ *Corresponding Author: Email s_k_jain@yahoo.com
}

\begin{abstract}
A large population depends on runoff from Himalayan rivers which have high hydropower potential; floods in these rivers are also frequent. Current understanding of hydrologic response mechanism of these rivers and impact of climate change is inadequate due to limited studies. This paper presents results of modeling to understand the hydrologic response and compute the water balance components of a Himalayan river basin in India viz. Ganga up to Devprayag. Soil and Water Assessment Tool (SWAT) model was applied for simulation of the snow/rainfed catchment. SWAT was calibrated with daily streamflow data for 1992-98 and validated with data for 19992005.Manual calibration was carried out to determine model parameters and quantify uncertainty. Results indicate good simulation of streamflow; main contribution to water yield is from lateral and ground water flow. Water yield and ET for the catchments varies between 43-46\% and 57-58\% of precipitation, respectively. The contribution of snowmelt to lateral runoff for Ganga River ranged between $13-20 \%$. More attention is needed to strengthen spatial and temporal hydrometeorological database for the study basins for improved modeling.
\end{abstract}

Keywords: Hydrological modeling, SWAT, Western Himalaya, calibration

\section{INTRODUCTION}

Many rivers, springs and lakes in the mountain regions are fed by significant contribution runoff from snow and glacier melt. The headwater catchments of most of the rivers in the Himalayan region such as the Ganga, the Indus and the Brahamaputra, lie in the snow covered areas. Snowfall is temporarily stored in high hills and the melt water reaches the river later in the hot season. Snow and glacier runoff are vital in making big Himalayan Rivers perennial whereas the rainfall contribution during the monsoon season is important for high flow volumes in rivers. Snow accumulates in the Himalayas generally from November to March, while melt season spans the months April to September. Snowmelt is the predominant component of runoff in mountains in April to June months and it forms a significant constituent of streamflows during July - September.

High spatial and temporal variability in hydro-meteorological conditions in mountainous environments requires spatial models that are physically realistic and computationally efficient (Liston and Elder, 2006b). Among the models developed to simulate hydrological response of mountainous basins, the most common approach followed for distributed snowmelt modeling in the absence of detailed measured data is to subdivide the basin into zones based upon elevation, allowing the model to discretize the snowmelt process based on watershed topography (Hartman et 
Hydrol. Earth Syst. Sci. Discuss., doi:10.5194/hess-2017-100, 2017

Manuscript under review for journal Hydrol. Earth Syst. Sci.

Discussion started: 28 March 2017

al., 1999; Li et al., 2013, 2015, 2016). The list of models developed for modeling response of a catchment subject to solid and liquid precipitation includes commercial software such as Mike-SHE (http://mikebydhi.com) and the public domain models such as the SWAT model (Neitsch, 2002), the Xinanjiang Model (Zhao et al., 1995)and the HBV model (Bergstrom, 1992). An obvious advantage of the public-domain models is the saving in cost and ease in sharing model set-ups. SWAT is a public-domain model that has been used extensively. A user-friendly interface to set-up the model in a GIS framework, detailed user's manual and a large user base are the main reasons for a number of applications of the SWAT model.

SWAT is a semi-distributed, continuous watershed modelling system, which simulates different hydrologic responses using process based equations. Most of the applications of the SWAT model have used daily or monthly time steps for simulation. Obviously, it has been comparatively easy to obtain higher values of Nash-Sutcliffe Efficiency (NSE) for monthly data than for the daily data. Further, SWAT model has been successfully applied to catchments with size of a few sq. km to thousands of sq. km. For example, Spruill et al., 2000 applied the SWAT model to simulate daily streamflows in a watershed in Kentucky covering an area of $5.5 \mathrm{~km}^{2}$ whereas Zhang et al., 2008 used it to simulate monthly runoff of a mountainous river basin in China covering area of $114,345 \mathrm{~km}^{2}$. Some more recent applications of SWAT for rainfall-runoff modeling are those by Jain et al., 2010, Shawul et al., 2013, Kushwaha and Jain, 2013, Khan et al., 2014, Tamm et al., 2016, Awan et al., 2016 and Singh et al., 2016. Tyagi et al., 2014 used it for sediment modelling and Pandey et al., 2014 and Tamm et al., 2016 used results of SWAT to estimate hydropower potential of a catchment.

Many studies have attempted to simulate water quality variables by employing the SWAT model. Jha et al., 2006 simulated streamflow, sediment losses, and nutrient loadings in the Raccoon River watershed and assessed impacts of land use and management practice shifts. Hafiz et al., 2012 examined applied the SWAT model to model flow, sediments and water quality parameters in upper Thachin River Basin, Thailand with catchment area of $5,693 \mathrm{~km}^{2}$. It was reported that the model gave good results. Qiu and Wang, 2014 applied the SWAT model to the Neshanic River watershed to simulate streamflow and water quality parameters including total suspended solids (TSS), total nitrogen (TN), and total phosphorus (TP). An attractive feature of the SWAT model is its ability to model the catchment response due to snow/glacier melt and rainfall. Many studies have harnessed this feature of the model. For instance, Lemonds et al., 2007 calibrated the SWAT model to the Blue River basin $\left(867 \mathrm{~km}^{2}\right)$ in Colorado (USA) by adjusting the snowmelt, snow formation, and groundwater parameters and obtained good fits to average monthly discharge values (NSE = 0.71). As per Stehr et al., 2009, the snow component of SWAT was capable of providing a reasonably good description of the snow-cover extension over a small Chilean Basin $\left(455 \mathrm{~km}^{2}\right)$. Pradhanang et al., 2011 compared snow survey data for the catchment of Cannonsville reservoir with model simulated snowpack and snowmelt at different elevation bands. When measured and simulated snowpack were compared, correlation coefficients ranging from 0.35 to 0.85 were obtained. Simulations of daily and seasonal streamflow improved when 3 elevation bands were used. Troin and Caya, 2014 demonstrated the ability of SWAT to simulate snowmelt dominated 
Hydrol. Earth Syst. Sci. Discuss., doi:10.5194/hess-2017-100, 2017

Manuscript under review for journal Hydrol. Earth Syst. Sci.

Discussion started: 28 March 2017

(c) Author(s) 2017. CC-BY 3.0 License.

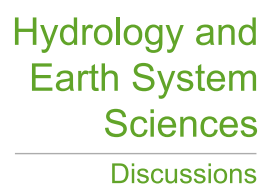

(c)

80 streamflow in the Outardes Basin, Quebec (Canada). The calibration of SWAT model showed a

81 satisfactory performance at the daily and seasonal time scales.

82

83

84

85

86

87

88

89

90

91

92

93

94

95

96

97

98

99

100

101

102

103

104

105

106

107

108

109

110

111

112

113

114

115

116

117

To improve the snow/glacier melt section of SWAT, some authors have attempted to develop and plug-in routines for these processes. For example, Fontaine et al., 2002 developed a snowfall-melt routine for mountainous terrain for the SWAT model which improved the correlation between observed and simulated stream flow.Recently, Luo et al., 2013 proposed a dynamic Hydrological Response Unit approach and incorporated an algorithm of glacier melt, sublimation/evaporation, accumulation, mass balance and retreat into the SWAT model. They simulated the transient glacier retreat and its impacts on streamflow at basin scale. This updated model was applied in the Manas River Basin (MRB) in northwest China and the authors obtained NSE of 0.65 for daily streamflow and small percent bias of $3.7 \%$ in water balance. The hydrological community at large can make good use of such innovations if the relevant software and guidelines for data preparation are made easily available.

Many other models or frameworks have been used in the recent past for modelling mountain catchments. Shrestha et al. (2013) developed energy budget-based distributed modeling of snow and glacier melt runoff in a multilayer scheme for different types of glaciers within a distributed biosphere hydrological modeling framework. A study of Hunza River Basin $\left(13,733 \mathrm{~km}^{2}\right)$ in the Karakoram mountains where the SWAT model was used showed good agreement with observations (NSE $=0.93$ ). Likewise, Immerzeel et al. (2013) used results from an ensemble of climate models along with a glacio-hydrological model for assessment of the impact of climate change on hydrologic response of two Himalayan watersheds: the Baltoro (Indus) and Langtang (Ganges). Future runoff was found to increase in both watersheds. A large uncertainty in future runoff arising from variations in projected precipitation between climate models was noted. It is hoped that the numerous attempts to apply the existing models to different geographies and research to develop new modeling theories would lead to significant advances in hydrology of mountain basins across the world.

Hydrological modeling of Himalayan river basins is important for many reasons. Nearly 2 billion people depend upon the waters of these rivers. Since most of these rivers are perennial and the terrain has steep slopes, they have huge hydropower potential whose exploitation requires a sound understanding of hydrologic response mechanism. Further, water triggered disasters are also frequent in these basins. The region has complex topography and hydrologic data are scarce. In addition, changes in land use/cover and climate are likely to significantly impact snow/glacier accumulation and melt and hydrological response of these river basins. Snow and glacier melt significantly contribute to flow of most Himalayan rivers and their modeling is an important component in streamflow modeling of Himalayan rivers. Global warming is likely to accelerate snow and glacier melt and it is necessary to study its impact for long term water resources planning. However, in spite of well-recognized importance and need of such studies, not many attempts have been made to assess hydrology of these rivers. 
Hydrol. Earth Syst. Sci. Discuss., doi:10.5194/hess-2017-100, 2017

Manuscript under review for journal Hydrol. Earth Syst. Sci.

Discussion started: 28 March 2017

Clearly, there is a need for better understanding of the hydrologic response of the Himalayan rivers for sustainable water management, developing the ability to forecast floods, and predict the impacts due to changes in climate and land use/cover. To that end, a distributed model is needed whose data requirements match with the availability. Although studies have been carried out in mountainous catchments with a variety of topography, climate, and data availability by using the SWAT model and the results have been quite good, only limited studies have been carried out in the Indian Himalayan region. The hydrological and other data of this region that are needed for modeling are not easily available and considerable efforts are required to collect and process the data and setup a distributed model. Therefore, the objective of this study was to improve our understanding of hydrological regime of the Himalayan rivers and enhance prediction of hydrological processes. The main goal was achieved through carrying out hydrologic modeling of a Himalayan river basin which receives contribution from snow/glacier and rainfall by employing larger amount of observed data. We have also attempted to determine various water balance components for better understanding of hydrologic response of the watershed. Better modeling and hydrologic assessment of these basins will help in improved management of water resources, harness hydropower potential, and partly overcome problems due to data scarcity. Such studies will also help understand the likely impacts of climate change on water resources.

Before proceeding further the SWAT model is briefly described in the following.

\section{THE SWAT MODEL}

The Soil and Water Assessment Tool (SWAT) is a semi-distributed, continuous time watershed modelling system which simulates hydrologic response of a catchment by using process-based equations. It has been developed by the USDA Agricultural Research Service (Arnold et al., 1998). Spatial variability in a catchment are represented in SWAT by dividing the catchment area into subwatersheds; these are further subdivided into hydrologic response units (HRUs). A HRU possesses unique land use, soil types, slope and management practices (Neitsch et. al., 2002a, 2002b). To computes the water balance, the model simulates a range of hydrologic processes such as evapotranspiration, snow accumulation, snowmelt, infiltration and generation of surface and subsurface flow components.

SWAT model allows division of maximum ten elevation zones in each sub-basin to consider orographic effects on precipitation, temperature and solar radiation (Neitsch et al., 2001). Snow accumulation, sublimation and melt are computed in each elevation zone and weighted average is computed subbasin wise. Snowmelt depth in the same elevation band is assumed to be the same in all sub-basins.

\subsection{Modeling of Snowmelt}

A temperature-index approach is used by SWAT model to estimate snow accumulation and melt. Snowmelt is calculated as a linear function of the difference between the average snowpack maximum temperature and threshold temperature for snowmelt. Snowmelt is combined with rainfall while calculating infiltration and runoff. SWAT does not include an explicit module to handle snow melt processes in the frozen soil, but includes a provision for adjusting infiltration and 
estimating runoff when the soil is frozen (Neitsch et al., 2005). Despite this limitation, SWAT is considered to be an appropriate integrated model for addressing a range of issues. It is noted that many of the existing models do not have the capability to model both snow/glacier melt and rainfall-runoff processes.

In the temperature-index approach, temperature is a major factor that controls snowmelt (Hock, 2003). Snowmelt is computed as a linear function of the difference between average snowpack maximum temperature and the threshold temperature for snowmelt, SMTMP:

$$
S N O_{m l t i}=b_{m l t i} \cdot S N O_{\text {covi }}\left[\frac{T_{\text {snowi }}+T_{\operatorname{maxi}}}{2}-S M T M P\right]
$$

Where $\mathrm{SNO}_{\text {mlti }}$ is the amount of snowmelt on day $\mathrm{i}\left(\mathrm{mm} \mathrm{H}_{2} \mathrm{O}\right), \mathrm{T}_{\operatorname{maxi}}$ is the maximum air temperature on day $\mathrm{i}\left({ }^{\circ} \mathrm{C}\right)$, SMTMP $\left({ }^{\circ} \mathrm{C}\right)$ is snowmelt base temperature above which snow will be allowed to melt and $b_{\text {mlti }}$ is the melt factor on day $\mathrm{i}\left(\mathrm{mm} \mathrm{H}_{2} \mathrm{O}\right.$-day). Snowmelt is included with rainfall in computation of infiltration and runoff.

The classification of precipitation is based on a threshold value of mean air temperature. If the average daily air temperature is below the snowfall temperature, the precipitation in a HRU is considered as solid (or snow) and the liquid water equivalent of the snowfall is added to snowpack. The snowpack is depleted by snowmelt or sublimation. The mass balance for the snowpack for a HRU is:

$$
S N O_{i}=S N O_{i-1}+P_{s}-E_{s u b i}-S N O_{m l t i}
$$

where, $\mathrm{SNO}_{\mathrm{i}}$ is the water content of the snowpack $\left(\mathrm{mm} \mathrm{H}_{2} \mathrm{O}\right), \mathrm{P}_{\mathrm{s}}$ is the water equivalent of snow precipitation $\left(\mathrm{mm} \mathrm{H}_{2} \mathrm{O}\right), \mathrm{E}_{\text {subi }}$ is the amount of snow sublimation $\left(\mathrm{mm} \mathrm{H}_{2} \mathrm{O}\right)$, and $\mathrm{SNO}_{\text {mlti }}$ is the water equivalent of snow melt $\left(\mathrm{mm} \mathrm{H}_{2} \mathrm{O}\right)$, all for day $i$.

The spatial non-uniformity of the areal snow coverage over the HRU is taken account through an areal snow depletion curve that describes the seasonal growth and recession of the snowpack (Anderson, 1976). Two addition parameters are defined at the watershed scale, SNOCOVMX and SNO50COV. These control the areal depletion curve by accounting for the variable snow coverage as:

$$
S N O_{\text {cov } i}=\frac{S N O_{i}}{S N O C O V M X}\left[\frac{S N O_{i}}{S N O C O V M X}+\exp \left(\operatorname{cov}_{1}-\operatorname{cov}_{2} \cdot \frac{S N O_{i}}{S N O C O V M X}\right)\right]^{-1}
$$

where $\mathrm{SNO}_{\text {covi }}$ is the fraction of $\mathrm{HRU}$ area covered by snow on the day $i, \mathrm{SNO}_{\mathrm{i}}$ is the water content of the snow pack on day $i$, SNOCOVMX is the minimum snow water content that correspond to $100 \%$ snow cover $\left(\mathrm{mm} \mathrm{H}_{2} \mathrm{O}\right)$, and $\operatorname{cov}_{1}$ and $\operatorname{cov}_{2}$ are coefficients that control the shape of the curve.

\subsection{Modeling of Catchment Hydrology}

Weather, soil properties, topography, vegetation and land management practices are the most important inputs for the SWAT model. SWAT computes actual soil water evaporation using an exponential function of soil depth and water content. The modified Soil Conservation Service 
(SCS) curve number method is used to compute runoff. The influence of plant canopy infiltration and snow cover is incorporated into the runoff calculation. To support soil water processes such as infiltration, evaporation, plant uptake, lateral flow, and percolation to lower layers, the soil profile is subdivided into many layers. When field capacity of a soil layer is exceeded downward flow occurs and the layer below is not saturated. Percolation from the bottom of the soil profile recharges the shallow aquifer. Lateral sub-surface flow in the soil profile is calculated simultaneously with percolation. Groundwater flow contribution to total stream flow is simulated by routing the shallow aquifer storage component to the stream. Runoff is routed through the channel network by the variable storage routing method or the Muskingum method (Neitsch et al., 2005).

SWAT model simulates hydrologic cycle based on the water balance equation:

$$
S W_{t}=S W_{o}+\sum_{i=1}^{n}\left(R_{d a y}-Q_{\text {surf }}-E_{a}-w_{\text {seep }}-Q_{g w}\right)
$$

where, $\mathrm{SW}_{\mathrm{t}}$ is the final soil water content $\left(\mathrm{mm} \mathrm{H}_{2} \mathrm{O}\right), \mathrm{SW}_{\mathrm{o}}$ is the initial soil water content (mm $\left.\mathrm{H}_{2} \mathrm{O}\right), t$ is time in days, $\mathrm{R}_{\text {day }}$ is amount of precipitation on day $i\left(\mathrm{~mm} \mathrm{H}_{2} \mathrm{O}\right), \mathrm{E}_{\mathrm{a}}$ is the amount of evapotranspiration on day $\mathrm{i}\left(\mathrm{mm} \mathrm{H}_{2} \mathrm{O}\right), \mathrm{Q}_{\text {surf }}$ is the amount of surface runoff on day $\mathrm{i}\left(\mathrm{mm}_{2} \mathrm{O}\right)$, $\mathrm{W}_{\text {seep }}$ is the amount of percolation and bypass exiting the soil profile bottom on day $\mathrm{i}\left(\mathrm{mm} \mathrm{H}_{2} \mathrm{O}\right)$, and $\mathrm{Qgw}_{\mathrm{gw}}$ is the amount of return flow on day $\mathrm{i}\left(\mathrm{mm} \mathrm{H}_{2} \mathrm{O}\right)$.

Since the model maintains a continuous water balance, the subdivision of the watershed in HRUs enables the model to consider differences in evapotranspiration for different crops and soils. Runoff is predicted separately for each sub area and is routed to compute total runoff for the basin.

SWAT model software and documentation are freely available through Internet at http://swat.tamu.edu/software/swat-executables/.

\subsection{Temperature index with elevation band approach}

This method incorporates elevation and temperature which is used to determine the snow pack and snowmelt caused by orographic variation in precipitation and temperature. Many studies, e.g., Zhang et al. (2008), have shown that elevation is an important factor in the variation of temperature and precipitation. Fontaine et al. (2002) introduced a modified snowfall-snowmelt routine for mountainous terrain into SWAT. This modified routine allows the SWAT model to divide each sub-basin into 10 elevation bands and simulates the spatial and temporal variation of snowpack and snowmelt on account of elevation. The temperature and precipitation for each elevation band was adjusted by using:

$T_{B}=T+\left(Z_{B}-Z\right) \cdot d T / d Z$

$P_{B}=P+\left(Z_{B}-Z\right) \cdot d P / d Z$ 
Hydrol. Earth Syst. Sci. Discuss., doi:10.5194/hess-2017-100, 2017

Manuscript under review for journal Hydrol. Earth Syst. Sci.

Discussion started: 28 March 2017

Hydrology and

Earth System

(c) Author(s) 2017. CC-BY 3.0 License.

Where, $\mathrm{T}_{\mathrm{B}}$ is the mean temperature $\left({ }^{\circ} \mathrm{C}\right)$ in the elevation band, $\mathrm{T}$ is the temperature measured at the weather station $\left({ }^{\circ} \mathrm{C}\right), \mathrm{Z}_{\mathrm{B}}$ is the midpoint elevation of the band $(\mathrm{m}), \mathrm{Z}$ is the elevation $(\mathrm{m})$ of the weather station, $P$ is the precipitation measured at the weather station $(\mathrm{mm}), \mathrm{P}_{\mathrm{B}}$ is the mean precipitation of the band $(\mathrm{mm}), \mathrm{dP} / \mathrm{dZ}$ is the precipitation lapse rate $(\mathrm{mm} / \mathrm{km})$, and $\mathrm{dT} / \mathrm{dZ}$ is the temperature lapse rate $\left({ }^{\circ} \mathrm{C} / \mathrm{km}\right)$.

\section{THE STUDY AREA AND DATA USED}

In the present study, Ganga River Basin up to Devprayag have been considered. The study area lies in the North- Western Himalayan ranges, between latitudes $30^{\circ}$ to $31^{\circ} 30^{\prime}$ North and longitudes $78^{\circ}$ $7^{\prime}$ to $80^{\circ} 15^{\prime}$ East in India and is shown in Figure 1.The size of the catchment is about 18728 $\mathrm{km}^{2}$ and elevation varies from $427 \mathrm{~m}$ to $7785 \mathrm{~m}$. Bhagirathi and Alaknanda Rivers are the two headwater streams that join at Devprayag to form Ganga River. The Bhagirathi River originates from the snout of the Gangotri Glacier at Gomukh $(3900 \mathrm{~m})$. It flows for $217 \mathrm{~km}$ to reach Devprayag and is joined by Bhilangana and Asiganga Rivers on the way. Asiganga joins Bhagirathi River at $5 \mathrm{~km}$ upstream $(1120 \mathrm{~m})$ of Uttarkashi from west direction. Bhilangana River originates from Khatling glacier $(3950 \mathrm{~m})$ and joins the Bhagirathi River at Tehri from east direction. Alaknanda River rises at the confluence and the foot of the Satopanth and Bhagirath Kharak Glaciers. The Alaknanda River flows for about $224 \mathrm{~km}$ before meeting with Bhagirathi River at Devprayag. Its main tributaries are Dhauli Ganga, Pindar, Nandakini and Mandakini. The average rainfall in the study area varies between 1000 to $2500 \mathrm{~mm}$, of which $60-80 \%$ falls during the monsoon period between June and September. The rivers experiences strong seasonal climatic variations, which is also reflected in the monthly variation in stream flows. High flow takes place during June-September, when the combined influence of rainfall and snow melt is at the maximum.

In this study, a number of maps have been prepared. The sources and resolution of ASTER DEM, land use land cover map and soil map are given in Table 1.

Meteorological data for the study area consisted of 16 years of time series (1990-2005) of daily precipitation, minimum and maximum temperature, solar radiation and wind speed for 7 stations, namely Badrinath, Joshimath, Karanprayag, Rudraprayag, Uttarkashi, Tehri and Devprayag. The rainfall data obtained for these stations were having many gaps. Therefore, precipitation data from Asian Precipitation - Highly-Resolved Observational Data Integration Towards Evaluation of Water Resources (APHRODITE's Water Resources) were used. The APHRODITE project develops state-of-the-art daily precipitation datasets with high-resolution grids for Asia. The datasets are created primarily with data obtained from a rain-gauge-observation network. APHRODITE's Water Resources project has been conducted by the Research Institute for Humanity and Nature (RIHN) and the Meteorological Research Institute of Japan Meteorological Agency (MRI/JMA) since 2006. A daily gridded precipitation dataset for 1961-2007 was created by collecting rain gauge observation data across Asia through the activities of the APHRODITE project (http://www.chikyu.ac.jp/precip/). The final data product does not have any gaps.

APHRODITE data is available in the form of grid of $0.5^{\circ} \times 0.5^{\circ}$ and $0.25^{\circ} \times 0.25^{\circ}$. The data of $0.25^{\circ} \times 0.25^{\circ}$ was downloaded for the period of 1961-2007 and converted into map form using 
Hydrol. Earth Syst. Sci. Discuss., doi:10.5194/hess-2017-100, 2017

Manuscript under review for journal Hydrol. Earth Syst. Sci.

Discussion started: 28 March 2017

(C) Author(s) 2017. CC-BY 3.0 License.

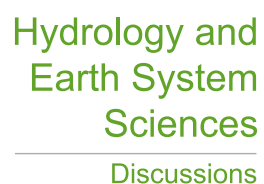

(c)

266

267

268

269

270

271

272

273

274

275

276

277

278

279

280

281

282

283

284

285

286

287

288

289

290

291

292

293

294

295

296

297

298

299

300

301

302

303

304

305

ArcGIS and exported to ERDAS Imagine. The grids for which data were downloaded and used in this study include Devprayag (altitude 469m), Tehri (608m), Rudraprayag (612m), Karnprayag (784m), Joshimath (1446m) and Badrinath (3136m).

Daily stream flow data collected from Central Water Commission (CWC) for gauging station located in the study area were used for model calibration and validation purpose. The discharge gauging station Devprayag-Z9 is located downstream of the confluence of Bhagirathi and Alaknanda rivers at Devprayag. The data measured at Devprayag-Z9 site were used to model the Ganga River Basin up to Devprayag.

\subsection{Land Use and Soil Data}

Land use is one of the most important factors affecting runoff, soil erosion and evapotranspiration in a watershed (Neitsch et al., 2005).

In the Ganga basin up to Devprayag, the most dominant land use/ land cover are open forest, dense forest, barren land, snow cover area and range land covering 23.28\%, 20.99\%, 13.41\%, $36.4 \%$ and $5.9 \%$ of the total basin area, respectively (Figure 2). For soils, Orthents (66\%), typicudorthents $(21 \%)$ and typiccryochrepts $(12 \%)$ are the most dominant soils having 2,3 and 3 layers respectively in the basin (Figure 3).

\subsection{Model Set Up}

In the setup of SWAT model for the study catchment, the first step is identification and delineation of hydrological response units (HRUs). River network for Ganga basin up to Devprayag were delineated from ASTER DEM by using the analytic technique of the ArcSWAT 2009 GIS interface(Figure 4).To obtain a reasonable numbers of HRUs within each subbasin, a unique combination of landuse and soil (thresholds of $10 \%$ in land use/land cover and 5\% in soil type) were used. In this procedure, the Ganga River Basin was divided into 7 sub-basins and 126 HRUs as shown in Figure 5. These set up ensures a stream network definition that satisfactorily represents the dominant land uses and soils within each subbasin and at the same time, a reasonable number of HRUs are created in each sub-basin.

The SWAT model has a large number of parameters that describe the different hydrological taking place in the study basin. During calibration process, model parameters were systematically adjusted to obtain results that best match with the observed values. In the validation process, the catchment response was simulated by using the parameters finally obtained during the calibration process. For evaluating the model performance computed hydrographs was compared with the observed hydrograph. It may be stated here that the streamflow data for the Ganga basin is classified and cannot be disclosed. Hence, we have shown scaled values of the flows in various graphs of Ganga basin.

The length of calibration data is an important factor in model calibration. The available data is usually partitioned in two sets: calibration data and validation data. Usually, calibration is carried out by using more years of data; say about $60-75 \%$ of the available data. Typical questions that arise in this respect are: how much data are necessary/enough to obtain a good model calibration 
Hydrol. Earth Syst. Sci. Discuss., doi:10.5194/hess-2017-100, 2017

Manuscript under review for journal Hydrol. Earth Syst. Sci.

Discussion started: 28 March 2017

and what are the characteristics that the calibration data should have to maximize the chances of obtaining reliable parameter estimates? Ideally, model calibration should result in parameter values that produce the best overall agreement between simulated and observed values (discharge in this case). Yapo et al., 1996 found that for the watersheds similar to their study area, approximately 8 years of data may be necessary to obtain a calibration that is relatively insensitive to the period selected and that the benefits of using more than 8 years of calibration data may be marginal. Regarding the characteristics, parameter identifiability significantly improves when the all the hydrologic components are activated during the calibration period.

Statistical performance measures of the hydrological models are computed to determine how the values simulated by the model match with those observed. For this study, the statistical criteria that were used to evaluate model performance were the goodness-of-fit $\left(R^{2}\right)$, the NashSutcliffe efficiency index (NSE) and coefficient of regression line multiplied by the coefficient of determination $\left(\mathrm{bR}^{2}\right)$. The model performance is considered to be better as the values of $\mathrm{R}^{2}$ and NSE approach unity.

The observed daily stream flow data from year 1990 to 1998 were used to calibrate the SWAT model and the model was validated by using the data from the year 1999 to 2005. Data for the first two years (1990 and 1991) were reserved as "warm-up" period (to overcome the errors due to incorrect initial conditions, the results of model run for a few initial periods are not used in analysis of results. These initial periods are termed as the warm up period). Thus the model calibration statistics was evaluated for the period 1992-1998.

\section{RESULTS AND DISCUSSIONS}

Initially, the SWAT-CUP which uses Sequential Uncertainty Fitting (SUFI2) algorithm developed by Abbaspour et al., 2007 was used in this study.SUFI2 is a multi-site, semi-automated global search procedure for model calibration and uncertainty analysis. The sources of uncertainties which includes temperature and rainfall parameters and measured data are accounted for in SUFI2. SUFI2 uses P-factor, the percentage of measured data bracketed by the $95 \%$ prediction uncertainty (95PPU), and the R-factor average width of the 95PPU band divided by the standard deviation of the measured data, to assess uncertainty. Abbaspour et al., 2007 have described SUFI2 algorithm in detail.

While studying theSUFI 2 calibration results, it was seen that in the table of monthly values of various water balance components produced by SWAT, snowfall had fairly high values in monsoon months whereas the study area does not receive snowfall in monsoon months (June to September). PLAPS and TLAPS were the parameters controlling the temporal distribution of precipitation (whether rain or snow). The calibrated values of PLAPS and TLAPS from the SWATCUP were 8.5 and -5.83 . To have realistic values of precipitation distribution, TLAPS and PLAPS were changed systematically and TLAPS equal to -4.0 and PLAPS equal to 8.55 yielded precipitation values which were realistic for the study area. However, as a result of this change, 
Hydrol. Earth Syst. Sci. Discuss., doi:10.5194/hess-2017-100, 2017

Manuscript under review for journal Hydrol. Earth Syst. Sci.

Discussion started: 28 March 2017

(C) Author(s) 2017. CC-BY 3.0 License.

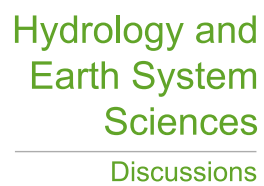

(c)

344

345

346

347

348

349

350

351

352

353

354

355

356

357

358

359

360

361

362

363

364

365

366

367

368

369

370

371

372

373

374

375

376

377

378

379

380

381

there were many significant deviations between observed and simulated hydrographs. In particular, the recession limbs and hydrograph during lean season had poor match as shown in Figure. 6.

At this stage, sensitivity analysis of model parameters was performed. Twenty calibrated parameters including seven snowmelt related parameters were used for sensitivity analysis. The sensitivity rank, default value, range of the parameter values and the optimal values for Devprayag sites in the basin are given in Table 2. The remaining parameters were not much sensitive for the model output.A number of SWAT parameters are related to snow but out of these, three parameters, viz. maximum temperature index melt factor SMFMX, the snowmelt base temperature SMTMP and the minimum temperature index melt factor SMFMN were found to be important.

The parameters were ranked in terms of their sensitivity to the model calibration. These sensitive parameters were mainly responsible for changes in model output during calibration. Results showed that $\mathrm{CN}$ is the most sensitive parameter to changes in discharge. Next to $\mathrm{CN}$, the other parameters that were found to be sensitive are those related to soil and groundwater. Among these, ALPFA_BF is the baseflow recession constant.

For proper simulation of the hydrograph during post monsoon and lean season, the changes in hydrograph in response to changes in several key parameters were also studied. It is noted during sensitivity analysis that changes in some model parameters may cause different type of changes in the simulated discharge in different seasons (monsoon and post monsoon). For instance, if the value of $\mathrm{CN}$ is increased, the simulated streamflow increased from September to May but decreased from June to August. When the value of ALPHA_BF was reduced, the simulated streamflow was found to increase from October to March and decrease from April to September. When the value of SOL_AWC was decreased, the simulated streamflow increased from September to February and decreased from March to August. When the value of SOL_K was increased, the simulated streamflow increased from February to August but decreased from September to January. When the value of GW_DELAY was increased, the simulated streamflow increased from March to August and decreased from September to February.

To improve the match between observed and simulated hydrographs in terms of recession limb and base flow, it was hypothesized that the movement of water through soil and ground water zone is not being properly modeled. Since baseflow was being under-simulated, more water should be allowed to enter the sub-surface zone, stay there for some time, and then emerge as baseflow. Accordingly, several simulations were carried out by changing the soil and ground water related parameters till the simulated hydrographs shows a good match with the observed hydrograph. The parameters that were systematically tuned include ALPHA_BF, SOL_AWC, SOL_K, and GW_DELAY. Two statistical performance measures (coefficient of determination $\mathrm{R}^{2}$ and NSE) and visual inspection of the plot between observed and computed hydrographs were used to evaluate the performance of the model in simulating streamflows and to decide which parameters to change.

The hydrographs of the observed and simulated daily and monthly flows for the calibration period (1992-1998) for the Ganga Basin up to Devprayag are shown in Figure 7a and 9a. It is seen 
Hydrol. Earth Syst. Sci. Discuss., doi:10.5194/hess-2017-100, 2017

Manuscript under review for journal Hydrol. Earth Syst. Sci.

Discussion started: 28 March 2017

that the overall shape of the simulated hydrograph is matching well with the observed hydrograph and the recession behaviour is also well simulated now. A few of the observed high peaks have been simulated well while some of the peak values do not match well. The time series of the observed and simulated daily and monthly hydrographs for the validation period are shown in Figure $8 \mathrm{a}$ and 10a. It is seen from the graph that the simulated hydrograph correlates significantly well with observed hydrograph. Scatter plot between observed and simulated daily and monthly discharges for the calibration data (Figure $7 b$ and $9 b$ ) indicate even distribution of most of the points around the 1:1 line. Of course, a few data points are away from the line. Further, for the validation period, the scatter plot for daily and monthly (Figure $8 \mathrm{~b}$ and 10b) also shows the points of the simulated flows are close to the $45^{\circ}$ line.

The statistical performance indicators for calibration and validation for the Ganga basin up to Devprayag are given in Table 3. The coefficient of determination $\left(R^{2}\right)$ was 0.69 and 0.95 for daily and monthly calibration period and 0.57 and 0.94 for daily and monthly during validation period. The NSE was computed as 0.64 and 0.80 for daily and monthly calibration period and 0.49 and 0.85 for daily and monthly validation period. Thus one may conclude that the indices for monthly data are excellent and can be termed as very good for the daily data. Figure 11 show the plot of observed and computed hydrograph for one year. It can be seen that some peaks have been properly simulated but some are not. It is highlighted that the density of raingauge network in the study area is grossly inadequate. Due to this many rainfall events that occur in the vicinity contribute large volumes of water in the model even though their spatial coverage may be small. On the other hand, if the event does not occur around the raingauge will be missed even though it may have a large spatial coverage.

For calibration and validation, various water balance components are given in Table 4 . The water balance components include: the total amount of precipitation, actual evapotranspiration, snowmelt runoff, and water yield. Here, water yield includes surface runoff, lateral flow to stream and water from shallow aquifer that returns to river reach. The results indicate that contribution from direct surface runoff is small in the water yield and the main contribution to water yield is through lateral flow and ground water flow. ET comes out to be $43-46 \%$ of precipitation. As catchment of Ganga river up to Devprayag site has comparatively less snow covered area, ET is at higher rate. The snowmelt runoff contribution at Devprayag site comes out to be $20 \%$ and $13 \%$ of the water yield during calibration and validation respectively. The water yield, i.e. sum of surface runoff, lateral runoff and ground water contribution in stream flow comes out be about $57-58 \%$ of the precipitation. In the basin, interflow contributes significantly to the water yield as compared to shallow groundwater.

\section{CONCLUSIONS}

This study has attempted to simulate the response of hilly parts of a Himalayan river basin, viz., the Ganga basin up to Devprayag. The values of $\mathrm{R}^{2}$ and NSE for calibration (1992-1998) and validation (1999-2005) vary between 0.69and 0.64 and can be considered as good (as per Moriasi et al., 2007) 
Hydrol. Earth Syst. Sci. Discuss., doi:10.5194/hess-2017-100, 2017

Manuscript under review for journal Hydrol. Earth Syst. Sci.

Discussion started: 28 March 2017

for the basin given the availability of meteorological and pedological data. Overall, the hydrograph shape could be reproduced satisfactorily although all the peaks and the recession limbs could not be reproduced very well. Thus, the SWAT model can be considered to be a good tool to model the discharge hydrograph and various water balance components for a Himalayan basin.

Water yield for the basin is ranging between $57-58 \%$ of the precipitation. Snow/glacier melt contribution is $13-20 \%$ for the Ganga basin. In the Ganga basin, interflow contributes significantly to the water yield. However, these results are required to be buttressed by more detailed hydrologic modeling of some more river basins to investigate their response mechanism. To that end, more attention is needed to strengthen spatial, soil and hydrometeorological database including snowfall for the study basins by installing automatic weather stations to measure precipitation (rain and snow) and other climatic variables at various elevations. Isotope analysis may be carried out to separate the runoff components and compare the results with hydrologic model.

\section{REFERENCES}

Abbaspour, K. C., Yang, j., Maximov, I., Siber, R., Bogner, K., Mieleitner, J., Zobrist, J., and Srinivasan, R.: Modelling hydrology and water quality in the pre-alpine/alpine Thur watershed using SWAT. Journal of Hydrology, 333, 413- 430, 2007.

Anderson, E.A.: A Point Energy and Mass Balance Model of Snow Cover. In: Development of a Snowfall-Snowmelt Routine for Mountainous Terrain for the Soil Water Assessment Tool (SWAT), T.A., Fontaine, T.S. Cruickshank, J.G. Arnold, and R.H. Hotchkiss (Editors), 1976.

Arnold, J.G., Srinivasan, R., Muttiah, R.S., and Williams, J.R.: Large area hydrologic modeling and assessment part I: model development J. Am. Water Resour. Assoc., 34, pp. 73-89, 1998.

Awan, U.K., Liaqat, U.W., Choi, M., and Ismaeel, A.: A SWAT modeling approach to assess the impact of climate change on consumptive water use in Lower Chenab Canal area of Indus basin. Hydrology Research, in press, 2016.

Bergstrom, S.: The HBV model-its structure and applications. SMHI Reports RH, No. 4, Norrkpoing, Sweden, 1992.

Fontaine, T.A., Cruickshank, T.S., Arnold, J.G., and Hotchkiss, R.H.: Development of a snowfallsnowmelt routine for mountainous terrain for the soil water assessment tool (SWAT). J Hydrol, 262(1-4):209-223, 2002.

Yasin, H.Q. and S.Clemente, R.: Application of SWAT Model for Hydrologic and Water Quality Modeling in Thachin River Basin, Thailand, Arabian Journal for Science and Engineering, Volume 39, Issue 3, pp 1671-1684, 2012.

Hartman, M.D., Baron, J.S., Richard, B.L., Donald, W.C., Larry, E.B., Glen, E.L., and Christina, T.: Simulations of Snow Distribution and Hydrology in a Mountain Basin. Water Resources Research, 35(5):1587-1603, 1999.

Hock, R.: Temperature index melt modelling in mountain areas. J Hydrol 282(1-4):104-115. doi:10.1016/s0022-1694(03)00257-9, 2003.

Immerzeel, W. W., Pellicciotti, F. and Bierkens, M. F. P.: 1004 Rising river flows throughout the twenty-first century in two Himalayan glacierized watersheds, Nature Geosci, doi:10.1038/ngeo1896, 2013.

Jain, S.K., Tyagi, J., and Singh V.: Simulation of runoff and sediment yield for a Himalayan Watershed using SWAT model. J. Water Resource and Protection, 2, 267-281, 2010. 
Hydrol. Earth Syst. Sci. Discuss., doi:10.5194/hess-2017-100, 2017

Manuscript under review for journal Hydrol. Earth Syst. Sci.

Discussion started: 28 March 2017

(C) Author(s) 2017. CC-BY 3.0 License.

Jha, M. K.; Arnold, J. G., and Gassman, P. W.: "Water Quality Modeling for the Raccoon River Watershed Using SWAT". CARD Working Papers. Paper 452. http://lib.dr.iastate.edu/card_workingpapers/452, 2006.

Khan, A.D., Ghoraba, S., Arnold, J.G., and Di Luzio, M.: Hydrological modeling of upper Indus Basin and assessment of deltaic ecology. International Journal of Modern Engineering Research. 4(1):73-85, 2014.

Kushwaha, A., and Jain, M.K.: Hydrological simulation in a forest dominated watershed in Himalayan region using SWAT model Water Resour. Manag., 27, pp. 3005-3023. http://dx.doi.org/10.1007/s11269-013-0329-9, 2013.

Lemonds, P.J., and McCray, J.E.: Modeling hydrology in a small rocky mountain watershed serving large urban populations. J. American Water Resour. Assoc. 43(4): 875-887, 2007.

Li, H., Beldring, S., Xu, C.Y., Huss, M., and Melvold, K.: Integrating a glacier retreat model into a hydrological model -- case studies on three glacierised catchments in Norway and Himalayan region. Journal of Hydrology 527, 656-667. doi:10.1016/j.jhydrol.2015.05.017, 2015.

Li, H., Xu, C.Y., Beldring, S., Tallaksen, T.M., and Jain, S.K.: Water Resources under Climate Change in Himalayan basins. Water Resources Management, in press. DOI:10.1007/s11269015-1194-5, 2016.

Li, L., Engelhard, M., Xu, C.Y., Jain, S.K., and Singh, V.P.: Comparison of satellite based and reanalysed precipitation as input to glacio hydrological modeling for Beas river basin, Northern India. Cold and Mountain Region Hydrological Systems under Climate Change: Towards Improved Projections. IAHS Publ. 360. 45-52, 2013.

Liston, G.E., and Elder, K.: A distributed snow evolution modeling system (SnowModel). Journal of Hydrometeorology, 7: 1259-1276, 2006.

Luo, Y., Arnold, J., Liu, S., Wang, X., and Chen, X.: Inclusion of glacier 1050 processes for distributed hydrological modeling at basin scale with application to a watershed in Tianshan Mountains, northwest China, J. Hydrol., 477, 72-85, 2013.

Moriasi, D.N., Arnold, J.G., Van Liew, M.W., Bingner, R.L., Harmel, R.D., and Veith, T.L. : Model evaluation guidelines for systematic quantification of accuracy in watershed simulations. Transactions of the American Society of Agricultural and Biological Engineers, 50(3): 885-900, 2007.

Neitsch, S.L., Arnold, J.G., Kiniry, J.R., and Williams, J.R.: Soil and water assessment tool (SWAT) theoretical documentation. Blackland Research Center, Texas Agricultural Experiment Station, Temple, TX, p 781, 2001.

Neitsch, S.L., Arnold, J.G., Kiniry, J.R., Srinivasan, R., and Williams, J,R.: Soil and Water Assessment Tool, User Manual, Version 2000. Temple, Tex.: Grassland, Soil and Water Research Laboratory, 2002.

Neitsch, S.L., Arnold, J.C., Kiniry, J.R., Williams, J.R., and King, K.W.: Soil and Water Assessment Tool Theoretical Documentation. Version 2000. Texas Water Resources Institute, College Station, Texas, USA, 2002a.

Neitsch, S.L., Arnold, J.C., Kiniry, J.R., Williams, J.R., and King, K.W.: Soil and Water Assessment Tool User's Manual. Version 2000. Texas Water Resources Institute, College Station, Texas, USA, 2002b.

Neitsch, S.L., Arnold, J.G., Kiniry, J., and Williams, J.R.: Soil and water assessment tool theoretical documentation, USDA Agricultural Research Service and. Texas A\&M Blackland Research Center, Temple, 2005. 
Hydrol. Earth Syst. Sci. Discuss., doi:10.5194/hess-2017-100, 2017

Manuscript under review for journal Hydrol. Earth Syst. Sci.

Discussion started: 28 March 2017

(C) Author(s) 2017. CC-BY 3.0 License.

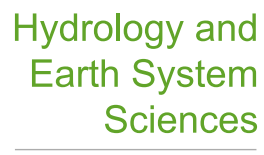

Discussions

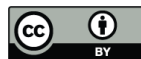

Pandey, A., Daniel, L., and Jain, S.K.: Assessment of hydropower potential using spatial technology and SWAT modeling in the Mat river of Southern Mizoram, India. Hydrological Sciences Journal (in press), 2014.

Pradhanang, S.M., Anandhi, A., Rajith, M., Zion, M,S,, Pierson, D..C, Schneiderman, E.M., Matonse, A., and Frei, A.: Application of SWAT model to assess snowpack development and streamflow in the Cannonsville watershed, New York, USA.Hydrol. Process. 25, 3268-3277, 2011.

Qiu, Z. and Wang, L.: "Hydrological and Water Quality Assessment in a Suburban Watershed with Mixed Land Uses Using the SWAT Model." J. Hydrol. Eng., 10.1061/(ASCE)HE.19435584.0000858, 816-827, 2014.

Shawul, A. A., Alamirew, T., and Dinka, M. O.: Calibration and validation of SWAT model and estimation of water balance components of Shaya mountainous watershed, Southeastern Ethiopia, Hydrol. Earth Syst. Sci. Discuss., 10, 13955-13978, doi:10.5194/hessd-10-139552013, 2013.

Shrestha, B., Babel, M.S., Maskey, S., van Griensven, A., Uhlenbrook, S., Green, A. and Akkharath, I.: Impact of 495 climate change on sediment yield in the Mekong River Catchment: a case study of the Nam Ou Catchment, Lao 496 PD, Hydrol. and Earth Syst. Sci., 17(1), 1-20, 2013.

Singh, H.V., Kalin, L., Morrison, A., Srivastava, P., Lockaby, G., and Pan, S.:Post-validation of SWAT model in a coastal watershed for predicting land use/cover change impacts. Hydrology Research, DOI: 10.2166/nh.2015.222, in press, 2016.

Spruill, C.A., Workman, S.R., Taraba, J.L.: Simulation of daily and monthly stream discharge from small watersheds using the SWAT model. Trans. ASAE 43(6): 1431-1439, 2000.

Stehr, A., Debels, P., Arumi, J.L., Romero, F., and Alcayaga, H.: Combining the Soil and Water Assessment Tool (SWAT) and MODIS imagery to estimate monthly flows in a data scarce Chilean Andean basin. Hydrological Sciences Journal 54: 1053-1067, 2009.

Tamm, O., Luhamaa, A., and Tamm, T.: Modelling future changes in the North-Estonian hydropower production by using SWAT. Hydrology Research, in press, 2016.

Troin, M., and Daniel, C.: Evaluating the SWAT's snow hydrology over a Northern Quebec watershed. Hydrological Processes, 28(4), 1858-1873, 2014.

Tyagi, J. V., Rai, S. P., Qazi, N., and Singh, M. P.: Assessment of discharge and sediment transport from different forest cover types in lower Himalaya using Soil and Water Assessment Tool (SWAT). International Journal of Water Resources and Environmental Engineering, 6(1), 4966, 2014.

Yapo, P. O., Gupta, H. V., and Sorooshian, S.: Automatic calibration of conceptual rainfall-runoff models: Sensitivity to calibration data. Journal of Hydrology, 181(1-4), 23-48, 1996.

Zhang, X.S., Srinivasan, R., Debele, B., and Hao, F.H.: Runoff simulation of the headwaters of the Yellow River using the SWAT model with three snowmelt algorithms. J Am Water Resource Assoc, 44(1):48-61. doi:10.1111/j.1752-1688.2007.00137, 2008.

Zhao, R. J., Liu, X. R., and Singh, V. P.: The Xinanjiang model. Computer models of watershed hydrology, 215-232.Water Resources Publications, Highlands ranch, Colorado, 1995. 
Hydrol. Earth Syst. Sci. Discuss., doi:10.5194/hess-2017-100, 2017

Manuscript under review for journal Hydrol. Earth Syst. Sci.

Discussion started: 28 March 2017

556

557

558

559

Table 1: Sources and description of the input data for the Ganga Basin up to Devprayag

\begin{tabular}{llll}
\hline Data Type & Source & $\begin{array}{l}\text { Spatial/ } \\
\text { Temporal } \\
\text { Resolution }\end{array}$ & Description \\
\hline Topography & http://gdem.ersdac.jspacesystems.or.jp & $90 \mathrm{~m}$ & $\begin{array}{l}\text { Aster Digital Elevation } \\
\text { Model }\end{array}$ \\
$\begin{array}{l}\text { Land use/Land } \\
\text { cover }\end{array}$ & www.iitd.ac.in & $90 \mathrm{~m}$ & $\begin{array}{l}\text { Land-use } \\
\text { Classification }\end{array}$ \\
Soils & www.iitd.ac.in & & Soil Classification \\
Weather Data & APHRODITE DATA & $90 \mathrm{~m}$ & $\begin{array}{l}\text { Temperature, Solar } \\
\text { Radiation, } \\
\text { Speed, Precipitation, } \\
\text { Data }\end{array}$ \\
& Central Water Commission, Dehradun & Daily & $\begin{array}{l}\text { Daily stream flows } \\
\text { measured at the } \\
\text { gauging stations }\end{array}$
\end{tabular}

560

561

562

563

Table 2: Description of 20 calibration parameters: Sensitivity rank, Default value, Range and Optimal value

\begin{tabular}{|c|c|c|c|c|c|}
\hline Parameters & Description & $\begin{array}{l}\text { Sensitivity } \\
\text { Rank }\end{array}$ & $\begin{array}{l}\text { Default } \\
\text { value }\end{array}$ & Range & $\begin{array}{l}\text { Optimal } \\
\text { value }\end{array}$ \\
\hline $\mathrm{CN} 2$ & $\begin{array}{l}\text { Initial SCS runoff curve } \\
\text { number for moisture } \\
\text { condition II }\end{array}$ & 1 & $77-92$ & $35-98$ & $55-92$ \\
\hline TLAPS & Temperature Lapse Rate & 2 & 0 & -10 to 10 & -4.0 \\
\hline SOL_AWC & $\begin{array}{l}\text { Available water capacity of } \\
\text { the soil layer }(\mathrm{mm} / \mathrm{mm})\end{array}$ & 3 & $\begin{array}{c}0.067- \\
0.146\end{array}$ & $0-1$ & $\begin{array}{c}0.024- \\
0.053\end{array}$ \\
\hline SOL_K & 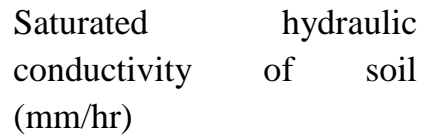 & 4 & $\begin{array}{l}1.95- \\
121.12\end{array}$ & $0-2000$ & $\begin{array}{c}3.0- \\
186.61\end{array}$ \\
\hline
\end{tabular}


Hydrol. Earth Syst. Sci. Discuss., doi:10.5194/hess-2017-100, 2017

Manuscript under review for journal Hydrol. Earth Syst. Sci.

Discussion started: 28 March 2017

(c) Author(s) 2017. CC-BY 3.0 License.

\section{Hydrology and Earth System Sciences \\ Discussions}

\begin{tabular}{|c|c|c|c|c|c|}
\hline SOL Z & Soil depth (mm) & 5 & $60-170$ & $0-3500$ & $30-300$ \\
\hline ALPHA_BF & $\begin{array}{l}\text { Base flow alpha factor } \\
\text { (days) }\end{array}$ & 6 & 0.084 & $0-1$ & 0.07 \\
\hline GW_DELAY & Groundwater delay (days) & 7 & 31 & $0-500$ & 35 \\
\hline REVAPMN & $\begin{array}{l}\text { Threshold depth of water in } \\
\text { the shallow aquifer for } \\
\text { "revap" to occur (mm) }\end{array}$ & 8 & 1 & $0-500$ & 499 \\
\hline RCHRG_DP & $\begin{array}{l}\text { Deep aquifer percolation } \\
\text { fraction }\end{array}$ & 9 & 0.05 & $0-1$ & 0.015 \\
\hline GW_REVAP & $\begin{array}{l}\text { Groundwater } \quad \text { revap } \\
\text { coefficeient }\end{array}$ & 10 & 0.02 & $0.02-0.20$ & 0.162 \\
\hline CH_K2 & $\begin{array}{l}\text { Effective hydraulic } \\
\text { conductivity in main } \\
\text { channel alluvium }(\mathrm{mm} / \mathrm{h})\end{array}$ & 11 & 0 & $\begin{array}{l}-0.01 \\
500\end{array}$ & 20.43 \\
\hline ESCO & $\begin{array}{l}\text { Soil evaporation } \\
\text { compensation factor }\end{array}$ & 12 & 0.95 & $0-1$ & 0.40 \\
\hline PLAPS & Precipitation Lapse Rate & 13 & 0 & $\begin{array}{c}-1000 \text { to } \\
1000\end{array}$ & 8.55 \\
\hline SMTMP & $\begin{array}{ll}\text { Snowmelt } & \text { base } \\
\text { Temperature }\left({ }^{\circ} \mathrm{C}\right) & \end{array}$ & 14 & 0.5 & -5 to 5 & -3.05 \\
\hline SMFMN & $\begin{array}{l}\text { Minimum melt rate for } \\
\text { snow during year (mm } \\
\mathrm{H}_{2} \mathrm{O} /{ }^{\circ} \mathrm{C} \text {-day) }\end{array}$ & 15 & 4.5 & $0-10$ & 0.80 \\
\hline SMFMX & $\begin{array}{l}\text { Maximum melt rate for } \\
\text { snow during year (mm } \\
\mathrm{H}_{2} \mathrm{O} /{ }^{\circ} \mathrm{C} \text {-day) }\end{array}$ & 16 & 4.5 & $0-10$ & 4.79 \\
\hline SNO50COV & $\begin{array}{l}\text { Snow water content } \\
\text { corresponding to } 50 \% \text { snow } \\
\text { cover }\end{array}$ & 17 & 0.50 & $0-1$ & 0.48 \\
\hline SFTMP & Snowfall Temperature $\left({ }^{\circ} \mathrm{C}\right)$ & 18 & 1 & -5 to 5 & -2.79 \\
\hline TIMP & $\begin{array}{l}\text { Snow pack temperature lag } \\
\text { factor }\end{array}$ & 19 & 1 & $0-1$ & 0.394 \\
\hline SNOCOVMX & $\begin{array}{l}\text { Minimum snow water } \\
\text { content corresponding to } \\
100 \% \text { snow cover, } \mathrm{SNO} 100 \\
\left(\mathrm{SNOCOVMX}-\mathrm{mm} \mathrm{H}_{2} \mathrm{O}\right)\end{array}$ & 20 & 1 & $0-500$ & 242.40 \\
\hline
\end{tabular}


Hydrol. Earth Syst. Sci. Discuss., doi:10.5194/hess-2017-100, 2017

Manuscript under review for journal Hydrol. Earth Syst. Sci.

Discussion started: 28 March 2017

569 Table 3: Statistical performance indicators for calibration and validation for Ganga River Basin up to Devprayag

571

572

573

574

575

576

\begin{tabular}{llll}
\hline \multirow{2}{*}{ Daily/Monthly } & $\begin{array}{l}\text { Calibration (1992-1998), } \\
\text { Validation(1999-2005) }\end{array}$ & $\mathrm{R}^{2}$ & NSE \\
& Calibration & 0.69 & 0.64 \\
\multirow{3}{*}{ Daily } & Validation & 0.57 & 0.49 \\
& Calibration & 0.95 & 0.80 \\
\multirow{2}{*}{ Monthly } & Validation & 0.94 & 0.85 \\
\hline
\end{tabular}

Table 4: Water balance components in $\mathrm{mm}$

\begin{tabular}{llllllll}
\hline Precipitation & ET & $\begin{array}{l}\text { Surface } \\
\text { Runoff }\end{array}$ & $\begin{array}{l}\text { Lateral } \\
\text { flow }\end{array}$ & $\begin{array}{l}\text { Ground } \\
\text { water } \\
\text { flow }\end{array}$ & $\begin{array}{l}\text { Water } \\
\text { yield }\end{array}$ & $\begin{array}{l}\text { Snow } \\
\text { fall }\end{array}$ & $\begin{array}{l}\text { Snow } \\
\text { melt }\end{array}$ \\
\hline
\end{tabular}

\begin{tabular}{lllllllll}
\hline Calibration & 1236.1 & 484.8 & 96.63 & 297.30 & 293.92 & 686.87 & 140.74 & 73.84 \\
Validation & 1203.3 & 512.1 & 74.24 & 299.37 & 290.05 & 662.81 & 110.57 & 48.87 \\
\hline
\end{tabular}


Hydrol. Earth Syst. Sci. Discuss., doi:10.5194/hess-2017-100, 2017

Manuscript under review for journal Hydrol. Earth Syst. Sci.

Discussion started: 28 March 2017

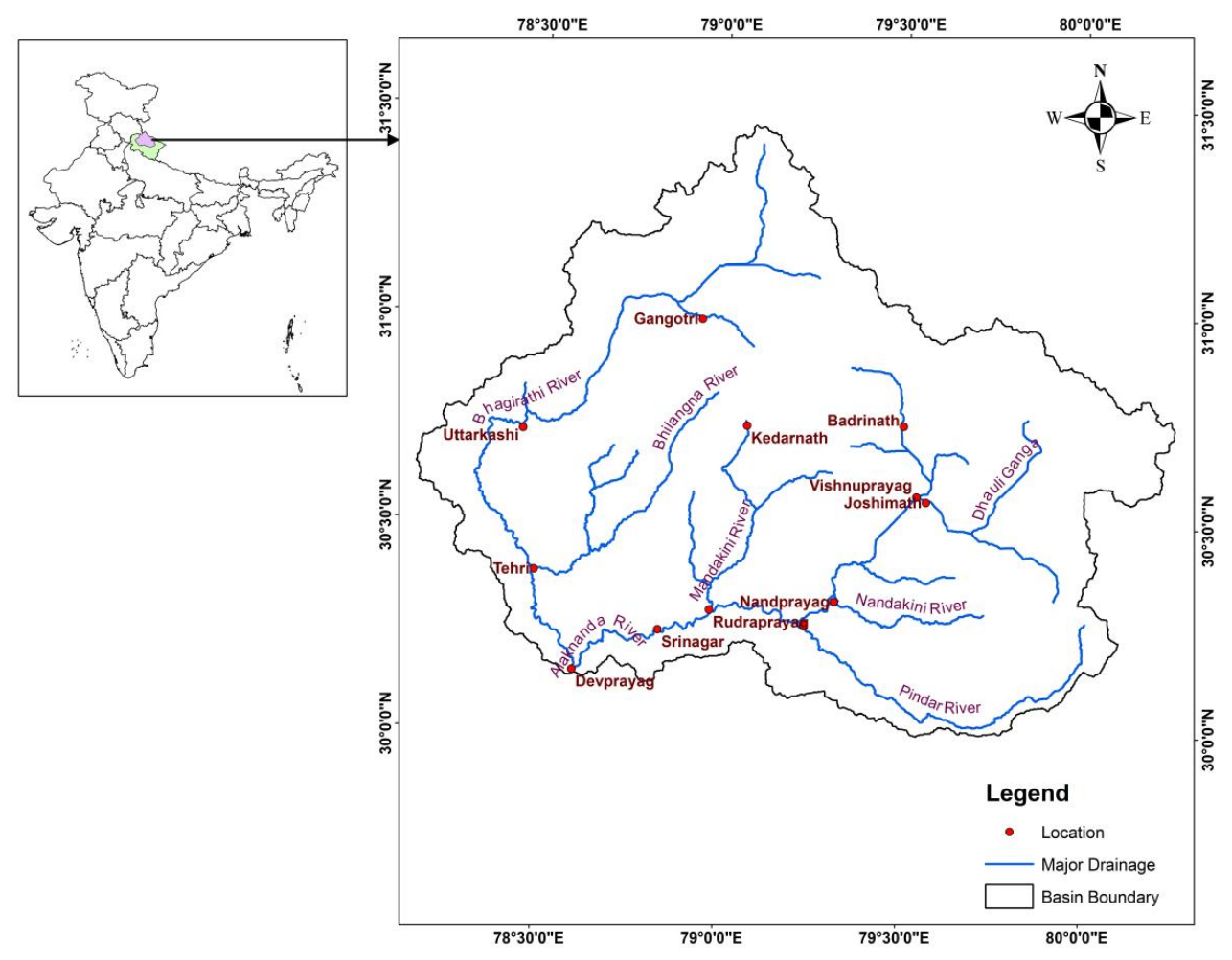

Figure 1: Index map of Ganga basin up to Devprayag 
Hydrol. Earth Syst. Sci. Discuss., doi:10.5194/hess-2017-100, 2017

Manuscript under review for journal Hydrol. Earth Syst. Sci.

Discussion started: 28 March 2017

(c) Author(s) 2017. CC-BY 3.0 License.
Hydrology and Earth System Sciences

Discussions

(c) (i)

644

645

646

647

648

649

650

651

652

653

654

655

656

657

658

659

660

661

662

663

664

665

666

667

668

669

670

671

672

673

674

675

676

677

678

679

680

681

682

683

684

685

686

687

688

689

690

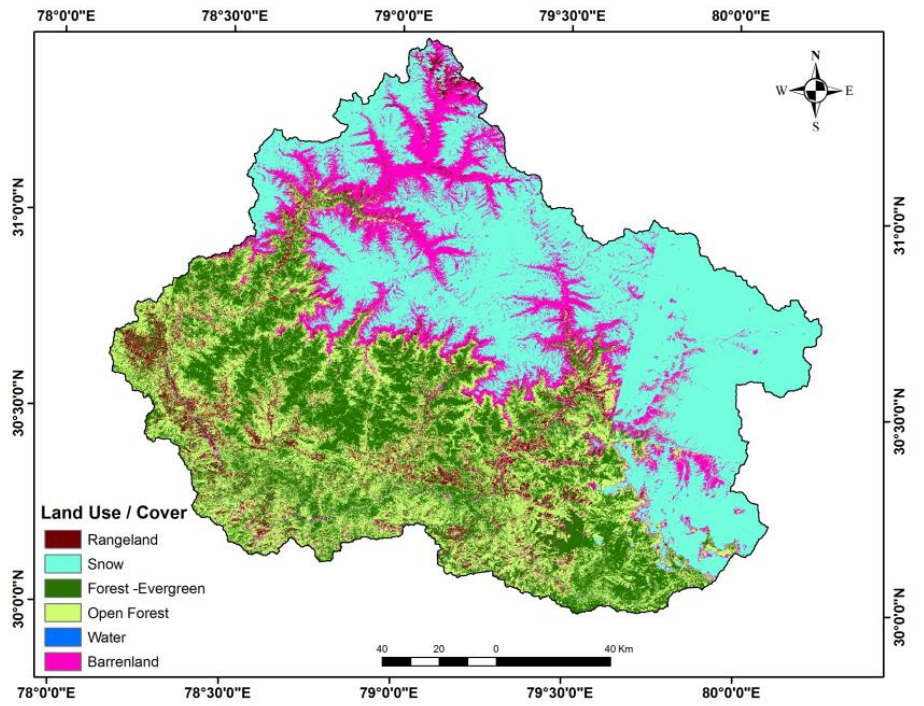

Figure 2: Land use/cover of Ganga basin up to Devprayag

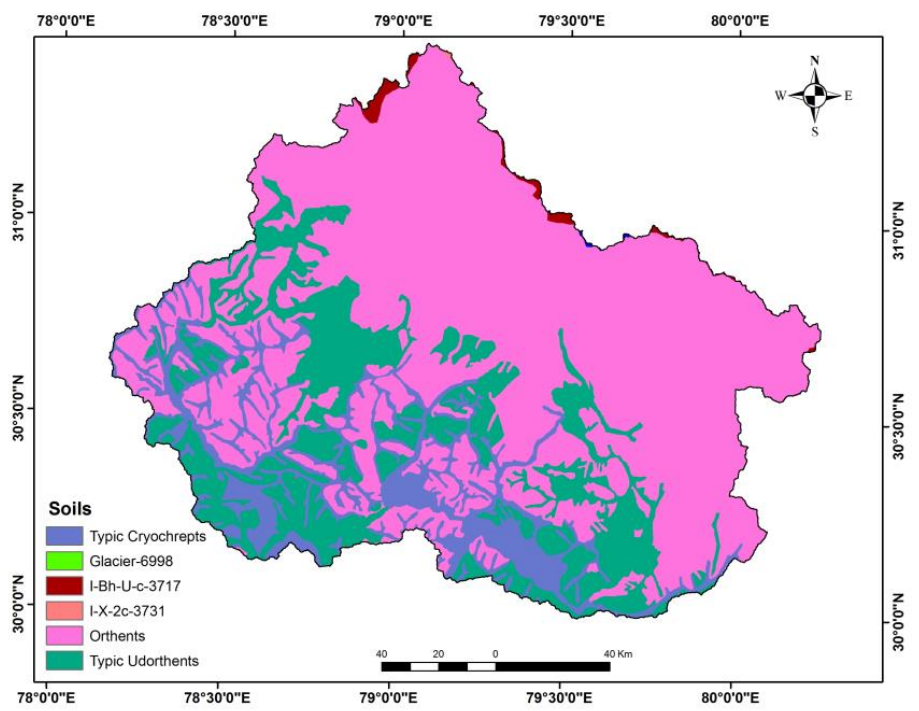

Figure 3: Soil map of Ganga basin up to Devprayag 
Hydrol. Earth Syst. Sci. Discuss., doi:10.5194/hess-2017-100, 2017

Manuscript under review for journal Hydrol. Earth Syst. Sci.

Discussion started: 28 March 2017

(c) Author(s) 2017. CC-BY 3.0 License.
Hydrology and Earth System Sciences

Discussions (c) (i)

691

692

693

694

695

696

697

698

699

700

701

702

703

704

705

706

707

708

709

710

711

712

713

714

715

716

717

718

719

720

721

722

723

724

725

726

727

728

729

730

731

732

733

734

735

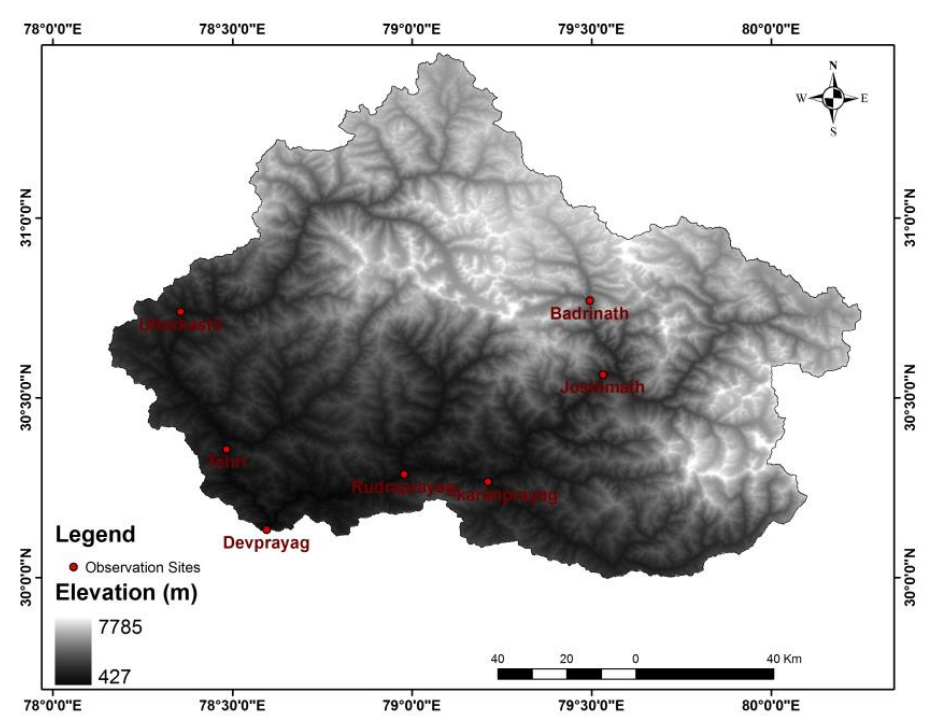

Figure 4: DEM of Ganga basin up to Devprayag

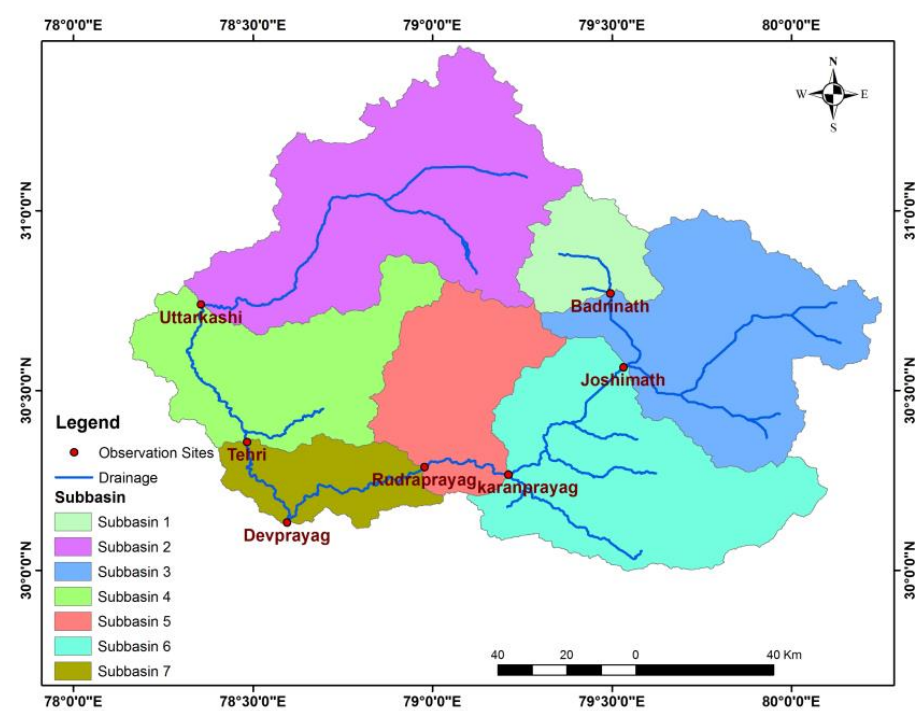

Figure 5: Sub basin map of Ganga basin up to Devprayag 
Hydrol. Earth Syst. Sci. Discuss., doi:10.5194/hess-2017-100, 2017

Manuscript under review for journal Hydrol. Earth Syst. Sci.

Discussion started: 28 March 2017

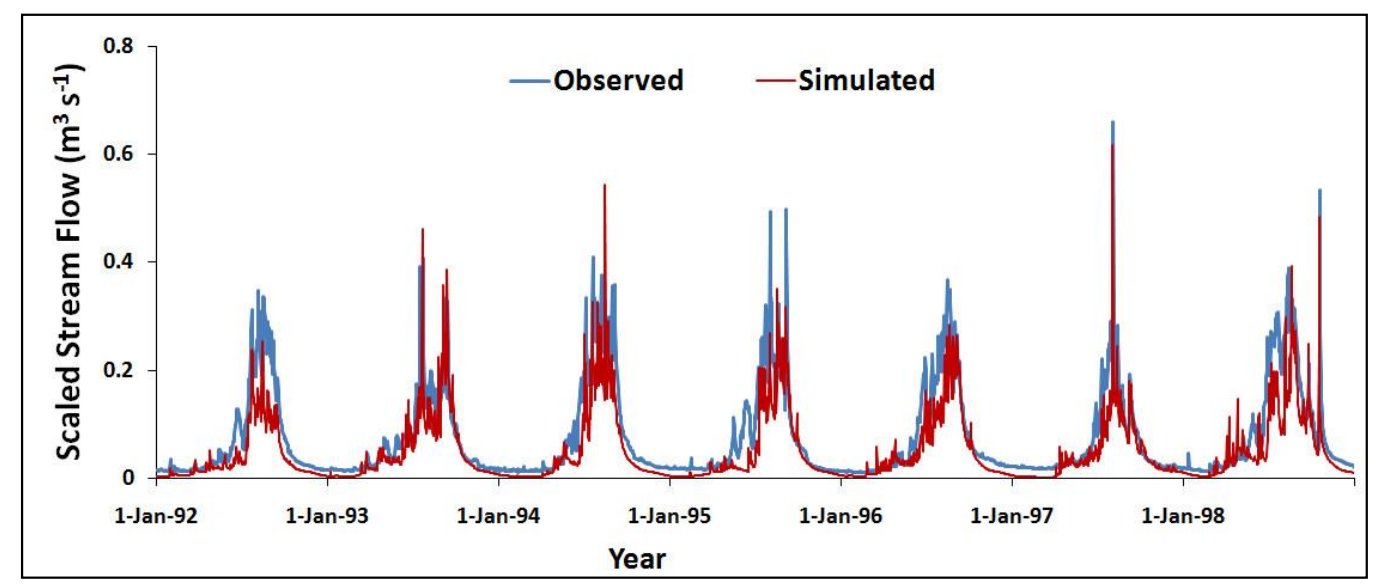

Figure 6: Comparison of daily observed and simulated stream flow hydrograph of Ganga basin up to Devprayag during calibration period (1992-1998) during iteration process 
Hydrol. Earth Syst. Sci. Discuss., doi:10.5194/hess-2017-100, 2017

Manuscript under review for journal Hydrol. Earth Syst. Sci.

Discussion started: 28 March 2017

(c) Author(s) 2017. CC-BY 3.0 License.
Hydrology and

\section{(c) (i)}
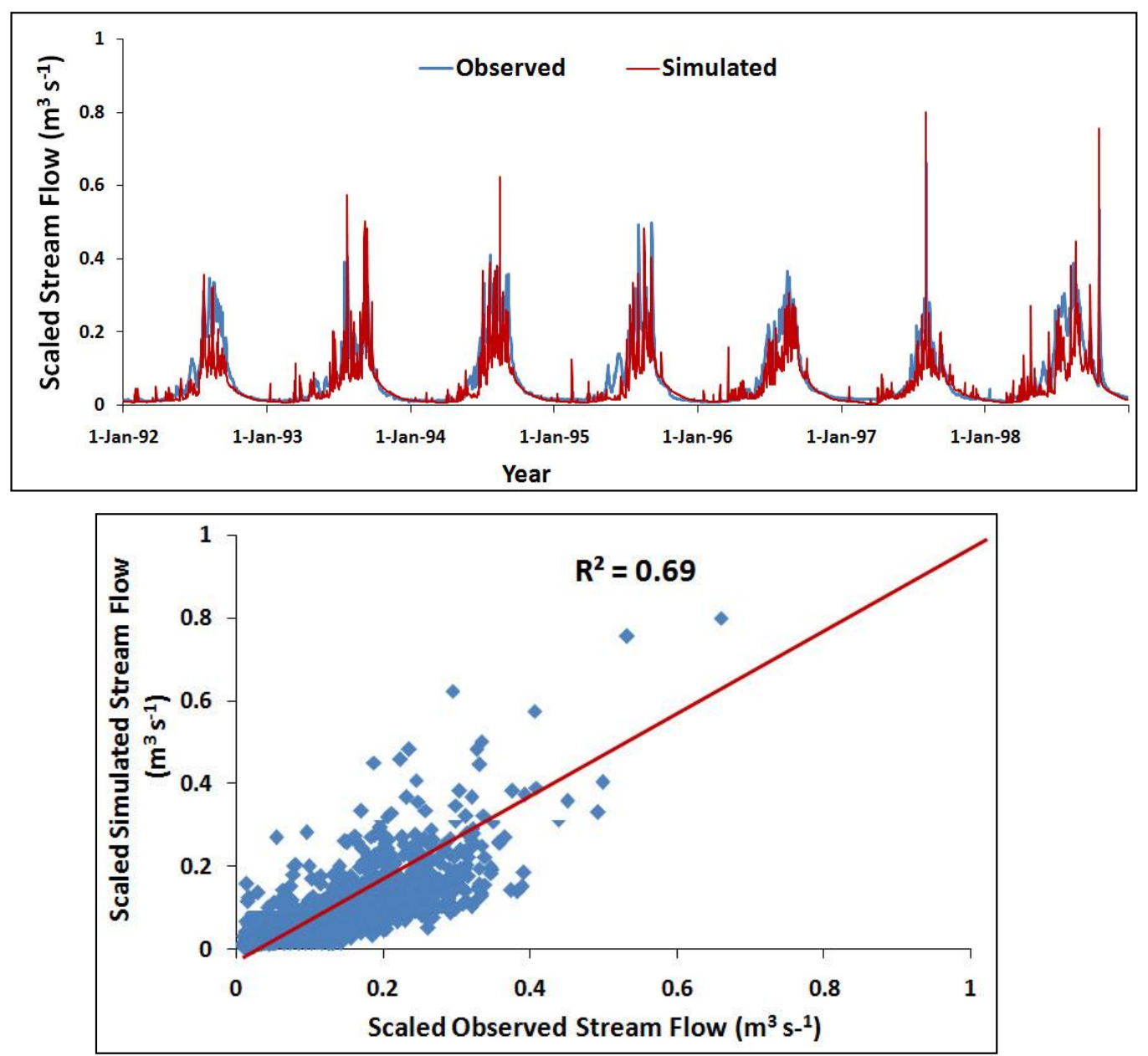

Figure 7: Comparison of a) daily observed and simulated stream flow hydrograph of Ganga basin up to Devprayag during calibration period (1992-1998), and b) scatter plot 
Hydrol. Earth Syst. Sci. Discuss., doi:10.5194/hess-2017-100, 2017

Manuscript under review for journal Hydrol. Earth Syst. Sci.

Discussion started: 28 March 2017

(c) Author(s) 2017. CC-BY 3.0 License.
Hydrology and

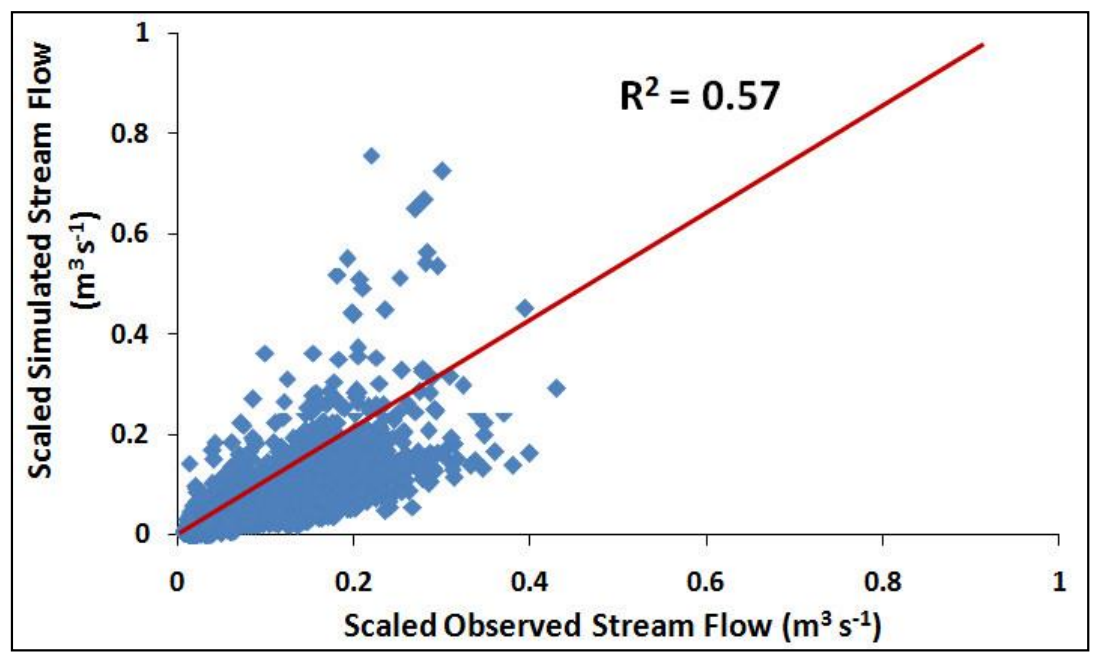

Figure 8: Comparison of a) daily observed and simulated stream flow hydrograph of Ganga basin up to Devprayag during validation period (1999-2005), and b) scatter plot 
Hydrol. Earth Syst. Sci. Discuss., doi:10.5194/hess-2017-100, 2017

Manuscript under review for journal Hydrol. Earth Syst. Sci.

Discussion started: 28 March 2017

Figure 9: Comparison of a) Monthly observed and simulated stream flow hydrograph of Ganga
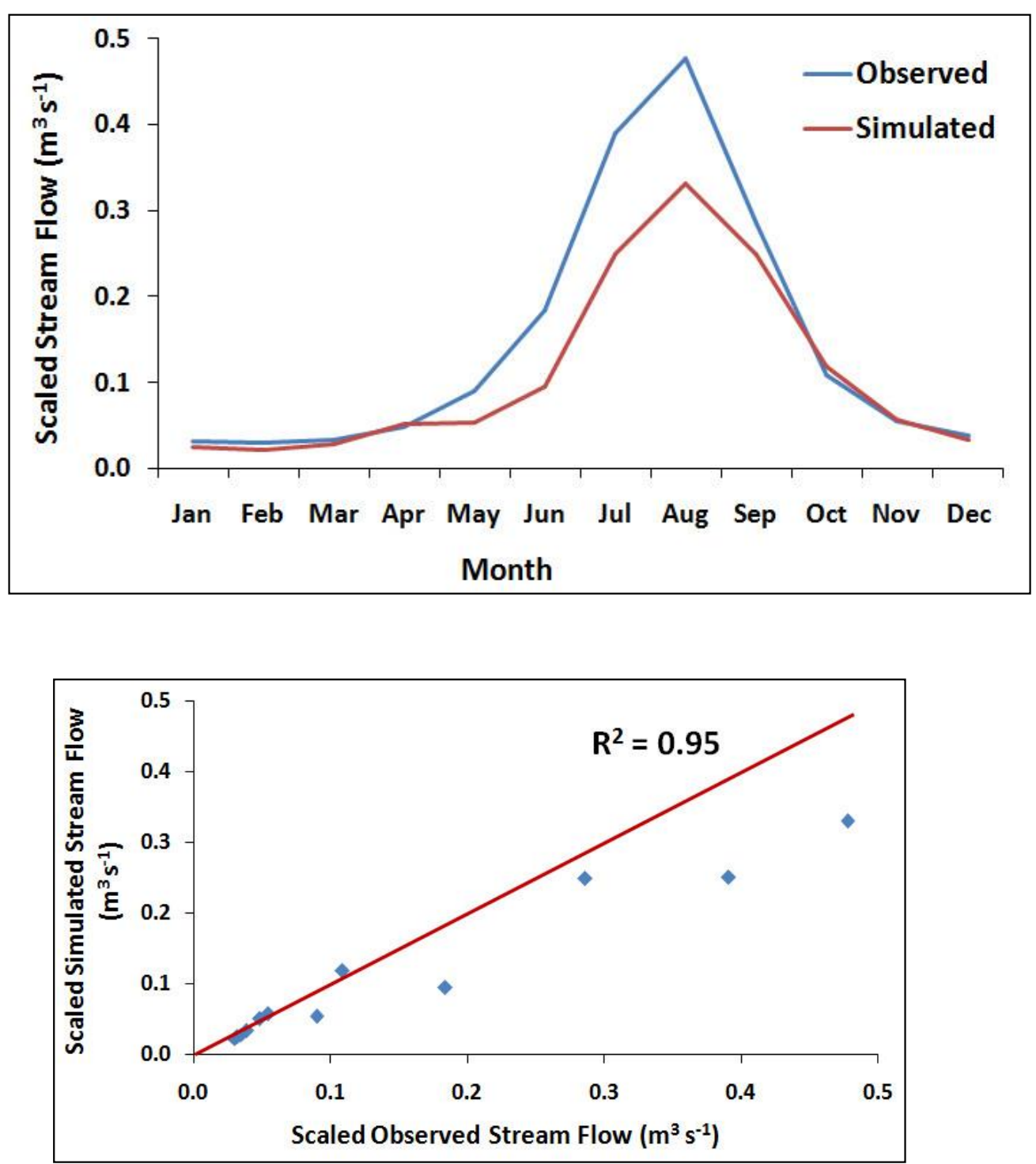
Hydrol. Earth Syst. Sci. Discuss., doi:10.5194/hess-2017-100, 2017

Manuscript under review for journal Hydrol. Earth Syst. Sci.

Discussion started: 28 March 2017

Figure 10: Comparison of a) Monthly observed and simulated stream flow hydrograph of Ganga
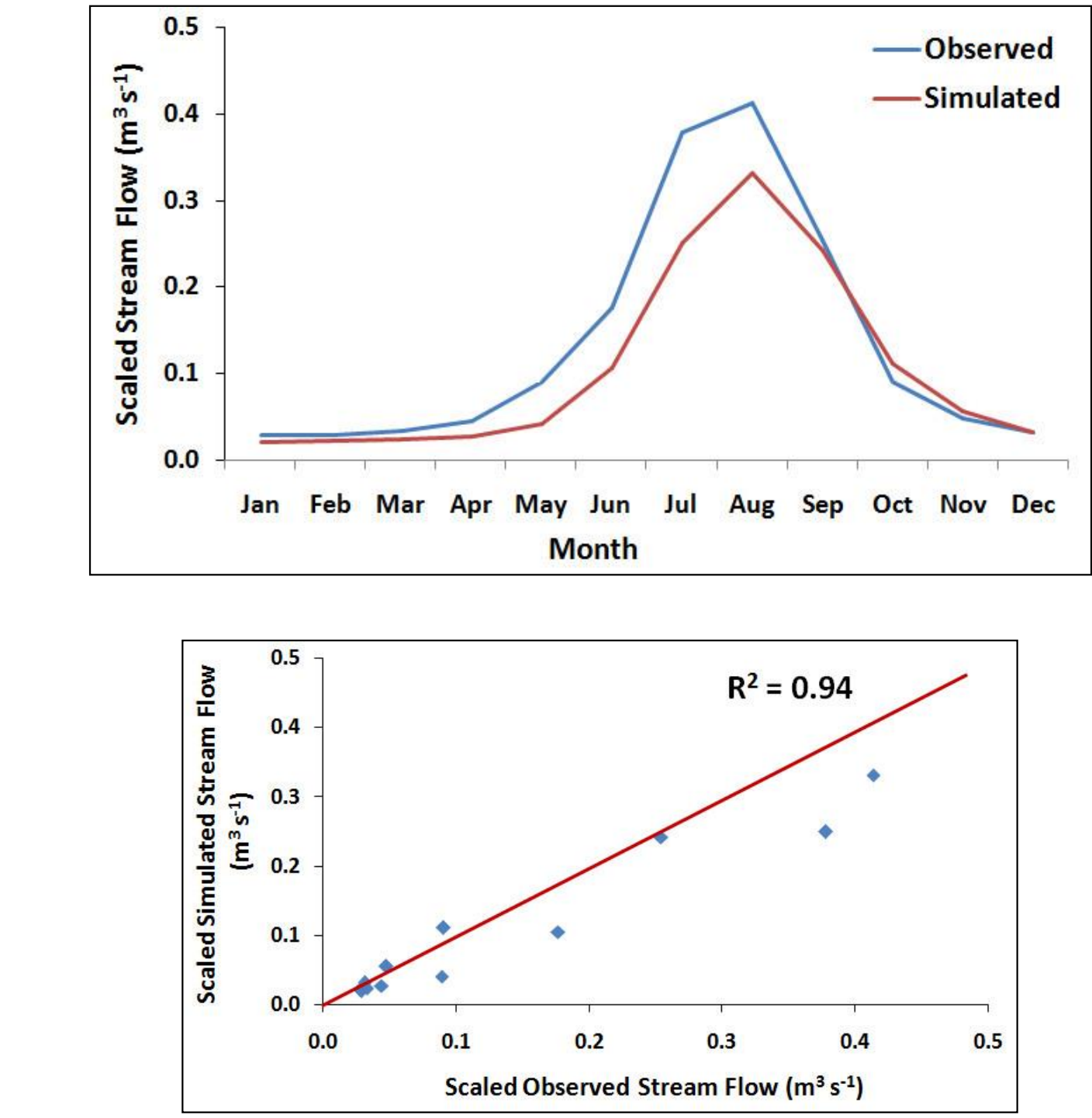
Hydrol. Earth Syst. Sci. Discuss., doi:10.5194/hess-2017-100, 2017

Manuscript under review for journal Hydrol. Earth Syst. Sci.

Discussion started: 28 March 2017

(C) Author(s) 2017. CC-BY 3.0 License.

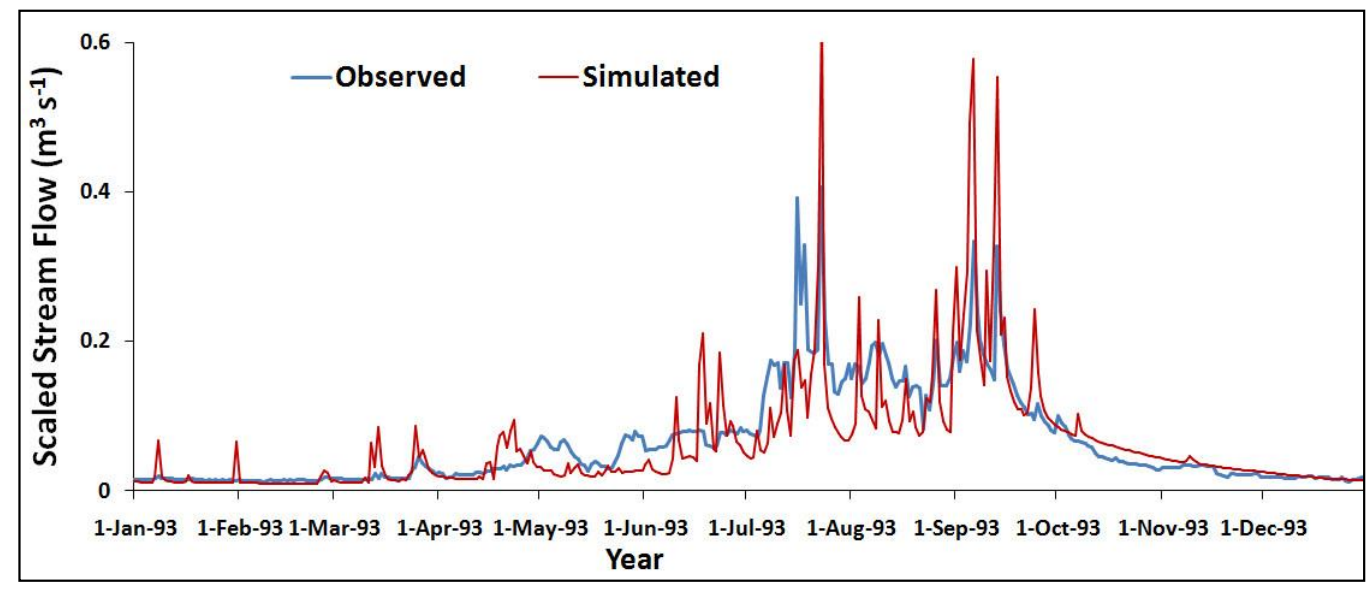

Figure 11: Daily observed and simulated stream flow hydrograph of Ganga basin up to Devprayag 989 